\title{
Beyond Hegemony: An Anthropological Approach to the Study of the Covid-19 Pandemic
}

\author{
Giovanni Pizza \\ Department of Philosophy, Social and Human Sciences and Education, \\ University of Perugia, Perugia, Italy \\ giovanni.pizza@unipg.it
}

\begin{abstract}
Starting from a Gramscian perspective, this article offers anthropological understandings of time in the experience of pandemics in Italy. The Gramscian suggestion is to go beyond hegemony in order to study the bodily life of powers. The author explores the anthropological sense of pandemics, also touching on philosophical approaches among contemporary studies. Following this, some questions about Italy are raised. What was the Italian experience of quarantine? Is it true that there was a 'failure' of the health model, above all in the northern regions, which had been praised as a pioneering model of public-private sector collaboration? Is it true to read the Covid-19 pandemic as evidence of 'victory' for Italy's central regions, such as the model of Umbria, with its centres of anthropological resistance? The instruments for answering these questions can be found in the critical anthropology of public health as outlined in the article.
\end{abstract}

\section{Keywords}

anthropology - Gramsci - time - pandemic - Italy - event - heterocrony

Amid the stresses of a global pandemic, the works of Antonio Gramsci can have a therapeutic effect. Immersing oneself in the study of his writings and reflections, at least two important points become very clear.

On the one hand, there is the fundamental, inescapable and timeless exercise of critique. Each one of us has the capacity to reflect, to think. It is a capacity that we must reclaim, a political agency that can transform the world, 
assuming we are not satisfied with the reality as it is. We can connect with those who want to transform reality and can start with language, changing the words used to define the world as a social reality.

On the other hand, there is the urgency of reappropriating the future, meaning to connect to our first need or to be aware of our inherent process as agency. We become part of a social network, and in this sense one can imagine oneself as a subject belonging to a reality, with a view to conquering one's own future.

These ideas are fundamental to the contemporary understanding of Gramsci's work. They can be boiled down to three keywords: body, nature and mutation (or transformation). These three keywords allow us to go beyond the notion of hegemony, which is an important concept that Gramsci uses to conceptualise the relationship between people and reality. Hegemony must not be confused with domination, but should be understood from the points of view of those who suffer it rather than only from the perspectives of those who exercise it.

Over the course of the current Covid-19 pandemic, in its various phases, we academics have become accustomed not only to forced seclusion, but also to a more thoughtful analytical reading of books and realities that had been waiting to be examined more closely. ${ }^{1}$ Our selves, even our 'scientific selves', are changing now, a result of the dramatic global crisis. My colleagues in the Italian Society of Cultural Anthropology (SIAC) and the Italian Society of Medical Anthropology (SIAM) and leading international anthropologists have approached the reading of the pandemic with different outcomes, all equally valid. Most of our colleagues in the social and human sciences, 'relatives' of anthropology, are still examining this epoch-making event. They are doing so for two reasons: first, to understand the socio-cultural and political implications of pandemics, and second, to make their intellectual tools available for the contemporary moment. A large body of respectable printed works has been produced, but equally respectable is silence. Silence is what Franco Basaglia described as an 'interval', needed above all by those who do not speak and do not write while knowing within themselves that the pandemic constitutes an important magnifying glass to observe social rules and the exceptions to them.

However, I do not intend to address here the very important dialogue with the biosciences. Rather, I aim to examine the following selective list of human and social scientists (in alphabetical order): anthropologists, pedagogues, philosophers, psychologists and sociologists, who have found domestic or public spaces (private or common places) that have mutated in different ways,

1 C. Pizza, 'Storie virali. Dad, Andrà tutto bene...' Treccani. Atlante, 4 April 202o, https://www. treccani.it/magazine/atlante/cultura/DAD_andra_tutto_bene.html. 
through analyses of the human basis of forced quarantines. This started with the contribution of students and professors, sometimes using telematic methodologies and/or widespread questionnaires.

Many of these works examine the human experience of time, establishing the plural character of its political dimension in the eyes of scholars predisposed to grasp its heterogeneity and showing the greater dispersion that it has manifested in this era.

The concrete materiality of the events pushes, in my opinion, anthropologists to look with greater attention to the masters of social and political thought, particularly Gramsci, ${ }^{2}$ who inspires the analytical gaze towards the events of today. It is the rhythm of his thought that, in my opinion, can inspire anthropology. Anthropology has produced many works, as have sociology, philosophy and other sciences. But the approach to the pandemic goes far beyond all disciplines, Gramsci's work is particularly inspiring. ${ }^{3}$

As a scholar, I felt the need to contribute to the study of the pandemic as an event of global magnitude that is still unfolding. Even though that event is more prolonged than we could have imagined, I will probably not make any new reflections. I started to write at the beginning of the pandemic, as a medical anthropologist, a column for Storie Virali that accompanied the first wave of the pandemic, as a sign of the consilience between anthropological-ethnographic perspectives on the present and historical-analytical perspectives on the past. Now I want to make explicit the Gramscian anthropological vocation of writing pandemics, connected to the possibility of changing reality through the words we use to represent it. Providing a critical view of our language is my first objective here.

Twenty years ago, the then centre-left government of Italy approved a law that modified the Constitution to provide individual Italian regions with federal powers to manage healthcare, so that it was no longer considered a burden for the state alone. The notorious law changed 'Title v' of the Constitution, 4 and the main political force that supported it at the time is now seeking to amend it. There have been too many deaths in Northern Italy during this pandemic, but not all of them can be blamed on the virus. Cuts in public health care, for example, are also responsible. The legislative demolition of public

2 G. Pizza, L'antropologia di Gramsci. Corpo, natura, mutazione (Rome: Carocci, 2020).

3 P. Saitta, 'Teorie nella crisi: pandemia e produzione culturale', in special issue of Materialismo Storico (2020), titled Pensare la pandemia: la soglia tra "pubblico" e "privato", la crisi attuale e le forme del potere, ed. S. G. Azzarà, F. Frosini and A. Garrido Fernández.

4 F. Palermo and S. Parolari, eds., Riforma costituzionale e regioni. Riflessioni a prima lettura sul nuovo Titolo V della Costituzione (Bolzano: Accademia Europea di Bolzano, 2015). 
primary health in Italy wrought by that law, bears at least as much responsibility as the virus. Specific political and economic choices have certainly overlapped with objective data - the greater incidence of urban settlement in Lombardy and the diminished population density in Umbria, for example - but there is no doubt that the Central Italian fragments of a 'district' and 'territorial' previous public health model are resisting. That could be considered a sort of 'Beveridgean' consequence of the right to health that was won in Europe after World War II. ${ }^{5}$

Following this, the question remains: what has happened in these months of quarantine in Italy? Have they made visible a 'failure' of the health model of the northern region of Lombardy, which had been praised as a pioneer of mixing the public and private sectors? Or can this be read as evidence of the 'victory' of southern Italy, such as the model of Umbria, with its centres of anthropological resistance like Tullio Seppilli's social use of anthropological work? ${ }^{6}$ Seppilli (1928-2017) was the founder of Italian medical anthropology and planned a project of understanding health as a 'common good', the results of which remain to be seen. We may not find out until after the event. But what is an 'event'? And what do we mean by saying 'after'?

There are at least five ways in which contemporary anthropology can study the 'event'. Stephanie Mauksch, ${ }^{7}$ a colleague from Leipzig who has long been committed to ethnographical observation of the enterprises of contemporary capitalism by combining anthropology with organisational and management studies, explains that an event, from an anthropological point of view, is:

1. a window on society

2. an instrument of action

3. a global form

4. a space of practice

5. a process

In relation to the COVID-19 pandemic, an event of burning topicality, those five ways of understanding an event seem to me to have in common the possibility of turning a global catastrophe into an opportunity for positive upheaval. Many observers, including academics, are grappling with a new perspective:

5 H. E. Sigerist, 'From Bismark to Beveridge: Developments and Trends in Social Security Legislation', Bulletin of the History of Medicine 13:4 (1943), 365-88, https://doi. org/10.2307/3343133; Atti del Convegno, 'La Sanità Pubblica in Umbria a 150 anni dell'Unità, held at the Sala dei Notari in Perugia 16 December 2011', Sistema Salute 56:1 (2012).

6 Pizza, L'antropologia di Gramsci 49-62.

7 S. Mauksch, 'Five Ways of Seeing Events (in Anthropology and Organization Studies)', in The Routledge Companion to Anthropology and Business, ed. R. Mir and A.-L. Fayard (New York and Oxford: Routledge, 2021), 357-77. 
they have, or believe they have, more time than before. What can this reveal about the moment?

To answer these questions, I suggest we focus on Mauksch's understanding of the event as a process. In the change that is rapidly evolving, I now look with growing sympathy at a statement that had left me perplexed thus far: in 2007, in one of his lectures, Tim Ingold argued that anthropology and ethnography are never the same thing. ${ }^{8}$ According to him, if anthropology looks comparatively and critically at human beings who inhabit the world to compare and generalise, ethnography is the tool that describes life forms in detail. We have often explained how the latter was the method of the former. But what is the process that unites them? Reflecting on what happens to us, all that remains for us to do is to cling to the dynamic notion of 'process' that grasps the facts in progress so we may try to make our hopes for future events bear fruit through our actions. As we know, one of the main founders of anthropological discourse, Alfred Reginald Radcliffe-Brown, was the first to make that distinction. ${ }^{9}$ Trained as a biologist in the concept of structure or generalisation, he wedded the clear differentiation between the natural and social sciences, separating anthropology from ethnography. Of course, I continue to think that he was wrong: I do not believe that the former is nomothetically devoted to making generalisations and the other by contrast is ideographically committed to observing living people, distinct only in this sense from the historiographic or archaeological method. It is a fact that anthropologists cannot speak without ethnography, and we can hardly ever indulge in fast opinionism. We may certainly speak in favour of Radcliffe-Brown, but we also say that another anthropologist of that same school of thought was more correct than his teacher. I am thinking of the leading scholar of social change, Max Gluckman, whose work took its impetus from the African context. ${ }^{10}$ Since the 1940s, he dealt with the theme of the proliferation of spaces and times, suggesting its methodological articulation in his ethnography of change. That is, he considered the event as a process between the extremes of historical discontinuity and social instantaneousness, between rupture and contingency. Of course, Gluckman was looking at the postwar crisis while we are looking at the COVID-19 pandemic. Today his ideas on change are forged between anthropology and philosophy,

8 Tim Ingold, 'Anthropology is Not Ethnography: Radcliffe Brown Lecture in Social Anthropology', Proceedings of the British Academy: 2007 Lectures 154 (2008), 69-92.

9 A. R. Radcliffe-Brown, 'The Methods of Ethnology and Social Anthropology', South African Journal of Science, 20 (1923), 124-47, DOI: 10.1525/aa.1920.22.4.02aooo2o; idem, Structure and Function in Primitive Society: Essays and Addresses (London: Cohen and West, 1952).

10 R. Werbner, Anthropology after Gluckman: The Manchester School: Colonial and Postcolonial Transformations (Manchester: Manchester University Press, 2020). 
to monitor the intensity that promises potential transformative developments in the events being examined.

But, military context aside, do the current and postwar crisis have anything in common? In today's communication systems related to the epidemic, the two crises are collapsing in a very literal sense. As Gluckman or his 'senior' pupil Victor Turner might have suggested, speaking of an event as a process means heightening the conflict that may arise from it - not continuing to conceal it out of a misunderstood sense of self-regulation, self-censorship or even opportunism, but rather giving voice, body and action to a struggle for the future.11

Introducing an important interview on the pandemic, Marina Davoli, ${ }^{12}$ Italian epidemiologist of Rome's First Local Health Office (ASL Roma 1), began with great clarity: 'Time in my opinion is the key word in the management of this epidemic'. Now, in the eyes of anthropology, the key word is perhaps not 'time' but 'the times', or even 'the politics of time. ${ }^{13}$ For instance, we can ethnographically detect times embodied in humans waiting, to evoke only one of the paradoxical physical forms to which our daily reflective experience of sociality is being reduced. In uno tempore, tempora multa latent, the great poet Tito Lucretius Carus wrote in De Rerum Natura in the first century вс. Today, Berardino Palumbo shows us the ethnographic and anthropological way to capture the workings of the heterochronies implicit in even the times of epic political struggle against global finance. ${ }^{14}$ Temporal plurality, therefore, forms part of a long-standing awareness. On the other hand, scholars of philosophy and politics, at least those who have taken seriously the Marxian concept of 'class' 15 because they are willing to criticise the West (i.e. to examine the frightening inequalities that characterise it), have always known this. ${ }^{16}$ They have

11 M. Gluckman, 'Analysis of a Social Situation in Modern Zululand', Bantu Studies 14:1 (1940), 147-74, https://doi.org/10.108o/o2561751.1940.9676107; Victor Turner, The Ritual Process. Structure and Anti-Structure, The Lewis Henry Morgan Lectures 1966 (London: Routledge, 1969).

12 Marina Davoli, 'Covid-19: l'importanza del tempo e della qualità dei dati', YouTube, 23 March 2020, https://www.youtube.com/watch?v=EojelScTMiM (accessed 29 March 2020).

13 Berardino Palumbo, 'Debt, Hegemony and Heterochrony in a Sicilian City', History and Anthropology 27:1 (2015), 93-106, https://doi.org/10.108o/o2757206.2015.1114479; D. L. Zinn, 'Time and Tide in Matera: European Capital of Culture 2019: Heterochronic Frictions', L'Uomo 9:2 (2019), 111-36, https://ojs.uniroma1.it/index.php/uomo/article/view/16555/15968.

14 Palumbo, 'Debt, Hegemony and Heterochrony in a Sicilian City'.

15 A. Cavalletti, Classe (Turin: Boringhieri, 2009). See also G. Agamben, A che punto siamo? L'epidemia come politica (Macerata: Quodlibet, 2020).

16 L. Basso et al., Tempora multa. Il governo del tempo (Milan: Udine, 2013). 
rethought it with Gramsci, for example. ${ }^{17}$ Perhaps, from this point of view, I would reverse the everyday metaphor studied by George Lakoff and Mark Johnson: not 'time is money', but "["filthy" - in agreement with Marx and also with the hygienists] money is time.18 We embody precisely that metaphor, here and now, within the four walls of our homes, or at least those of us who have four walls. In this way, then, we experience the strange illusion of time dilation. The pandemic is a day-after event. It always has been like that, and we can probably know it critically only afterwards and only with the positions that will later be taken concretely in the global social arena. Nonetheless, we now have to conquer that 'afterwards' for ourselves. But what will happen? Many are trying to foreshadow this. Some even manage to get a glimpse of it in the present. 'What will it be?', some ask. To answer, I would use the Perugian quasi-dialectal lexicon and, looking at the European discussion of 27 March 2020, I would say: 'Gli atti' $n$ son belli' (The moves are not good).

In conclusion, I think it best to leave a word about tomorrow to critical philosophers engaged with Italy today. The contemporary philosopher Rocco Ronchi, who is committed to probing the viral virtues of the moment, and for this reason very appealing to those like me who are willing not to put all the blame on the pathogen, has suggested the following: if the virus has the characteristics of an event (and it would be very difficult to deny it this trait), it must also have the 'virtue'. Events are such not because they 'happen' or, at least, not only because of that. Events are not 'facts'. Unlike simple facts, events have a 'virtue', a force, a property, a vis, because they do something. For this reason, the event is always traumatic, to the extent that we can say that where there is no trauma, there is no event - if there is no trauma, literally nothing happened. What do events actually do? They produce transformations. Before they took place, they weren't even possible. They start to be possible only 'after' they take place. The event, in short, is such because it generates the possible 'real'.19

Thanks Rocco, see you later.

17 P. Thomas, The Gramscian Moment: Philosophy, Hegemony, and Marxism (Leiden and Boston: Brill, 20o9); M. Filippini, Using Gramsci: A New Approach (London: Pluto Press, 2017); K. Crehan, 'Antonio Gramsci: Towards an Ethnographic Marxism', Anuac 7:2 (2018), 103-5o, https://doi.org/10.7340/anuac2239-625X-34532018.

18 G. Lakoff and M. Johnson, Metaphors We Live By (Chicago: University of Chicago Press, 1980).

19 My translation: R. Ronchi 'Le virtù del virus', Doppiozero, 8 March 2020, https://www. doppiozero.com/materiali/le-virtu-del-virus (accessed 29 March 2020). 


\section{Acknowledgement}

The author thanks his colleagues Christos Lynteris, Pompeo Martelli, Sabrina Perra and Dorothy L. Zinn for their kind help. A portion of this paper appeared in English in the blog Somatosphere, and in Italian as a section titled 'Dopo' [After], in a chapter titled 'Politiche del tempo all'epoca del Coronavirus' [Politics of Time in the Age of Coronavirus], co-authored by historians of medicine A. Carlino and M. Conforti, and anthropologists B. Palumbo, G. Pizza and P. Schirripa, in, Pandemia 2020. La vita quotidiana in Italia con il Covid-19 [Pandemic 2020: Daily Life in Italy with Covid-19], ed. Alessandra Guigoni and Renato Ferrari (Danyang: M\&J Publishing House, 2020), 56-70. 